\title{
The Gestalt Approach to Social Network Used by Generation X Parents
}

\author{
Adelma do Socorro Gonçalves Pimentel1, Gabriela Moreira de Faria ${ }^{2}$ \\ ${ }^{1}$ Graduate Program in Psychology, Federal University of Pará, Pará, Brazil \\ ${ }^{2}$ Psycholgy Faculty, Federal University of Pará, Pará, Brazil \\ Email: adelmapi@ufpa.br, gabi.faria91@gmail.com
}

Received 22 May 2015; accepted 18 September 2015; published 23 September 2015

Copyright (C) 2015 by authors and Scientific Research Publishing Inc.

This work is licensed under the Creative Commons Attribution International License (CC BY). http://creativecommons.org/licenses/by/4.0/

(c) (i) Open Access

\begin{abstract}
Studies on processes of subjectivation have shown changes in the way of individuals' interaction and interpersonal relations due to the use of new computer and communication technologies. Such attitudes demand abilities and competences that parents between age of 40 and 55, contrary to their children, do not always find it easy to learn; thereby, we aim to find how those parents understand the uses and meanings of the social networks. This is a qualitative research in psychology directed by a gestalt perspective, by Sander's phenomenological method. The research was approved by the ethics committee of Federal University of Pará. Semi-structured interviews were carried out with 6 parents chosen by the snow ball method. The data analysis consisted of a dialogue with references on the subjective effects of use of technologies. It is observed, among the results, that parents have used the social network to relate with their children and to work. It is concluded that, even though they have a limited knowledge of the technology, the informants use the social networks as a tool to find friends, for social interaction and prevention against urban violence and personal safety.
\end{abstract}

\section{Keywords}

Social Networks, Competences, Generation X, Qualitative Research

\section{Introduction}

This article shows the results of a qualitative exploratory research in hermeneutic phenomenological psychology, with gestalt approach. The theme is part of the Information and Communication Technology (ICT) scenario, focusing specifically on the use of social networks by "Generation X" parents. The objectives of the study were to identify the uses and contents posted on the social networks by parents in their 40 to 55 age bracket; to describe 
the purpose of social network use; to verify how its use has been incorporated in their daily lives, and if the way they use it affects the relation with their children. The analyses permitted understanding some of the senses and meanings of the virtual social networks given by the informants.

The relevance of the research is based in the social context where innumerous alterations occur in the compartments and in the processes of subjectivation of parents caused by the use of information and communication technology (ICT), especially in a more intensive way during the last decades of the $20^{\text {th }}$ century. With the advent and consolidation of the internet, it can be noticed that the social interactions and its psychological consequences have modified and taken different forms among the various age groups, from adolescents to middle aged adults and elders.

In a gestalt approach of social network use by parents we considered the gestalt concept of contact boundary in the analysis of the parents' performance and interaction in the social networks. According to Polster \& Polster (2001), the contact is more than the sum of all the other functions that comes with it, it is how one sees and hears certain individual or thing. Contact is a meeting, an exchange that exists in the interaction with both animate and inanimate objects, memories and images. To be in contact means that the individual will remain unchanged, because it does not require an effort for changes, it just happens during the interaction, because change is the inevitable product of contact.

According to the mentioned authors, contact occurs in a boundary where a sense of separation is maintained, so that the union may happen, but not suffocate or overload the individual. Thus, to Polster \& Polster (2001: p.115) "the contact boundary is the point where the individual experiences the "me" in relation to what is "not-me".

There are several types of contact boundaries, which may flexible or rigid, depending on how the person has lived through certain experiences, and how he or she uses these life experiences. Among the existing boundaries, we emphasize the body boundaries, the value boundaries and the boundaries of exposition. The body boundary concerns how a person relates with his/her body, the corporal conscience he/she owns and how he/she disposes the body during contact, if she/she permits to be touched, embraced or keeps a distance, and also which parts of the body are permitted to be exposed. Considering things from this angle, it is possible to investigate how Generation $\mathrm{X}$ parents interact on the social networks within their contact boundaries.

\section{Computer Technology and Communication Dynamics}

According to Castells (2010), internet is a technology used for the first time in 1969, in the United States. By the end of the $20^{\text {th }}$ century, it began to have new functions, being used for creation, communication and recreation, and also as instruments of virtual interaction. In sum, one may consider that the impacts of cyber culture are diverse in the subjectivation process of parents and children, demanding further studies due to specie of confluence established between society and technicality.

If it is necessary to master a language to visit cyber-space in a regular basis, the point in dispute is the quality of family communication in the web environment formed by a free structure of circulation of messages and information in a multidirectional, chaotic, entropic manner, at the same time individualized and personalized.

As for the social networks, they are defined by Wasserman \& Faust (1994) and Wellman (1997) as a set of two elements: players and connections. The players are called "we" and are known for being people, institutions or groups, while connections are social bonds set by the players. Capra (2008) adds that the social networks are also communication nets concerning symbolic language, power relations, constructions and cultural restrictions. The author states that the nets are complex, dynamic, self-generative structures whose production is immaterial.

According to Barcelos, Passerino and Behar (2010), a new form of social relationship that begins to surge is the internet social networking (ISN) or virtual social networking. As for Recuero's definition (2009), ISN may be of two types: 1) emergent, defined as connections originating from interpersonal exchanges measured by social interaction and conversation, for example, the blogs, photologs and WhatsApp ${ }^{\mathrm{TM}}$. They are emergent for they are constantly being constructed and reconstructed by social exchanges; 2) filiation, characterized for constructing mechanisms of associations in the social network sites, belonging or having a profile on Facebook and Twitter, among others. Such tools are used to share photos, videos and comments as instruments to teach-learn, and in a negative way, to promote cyberbullying (Pimentel \& Diniz, 2014).

\section{Methodology}

With the advance, according to Minayo (1994/2013), Qualitative Research (QR) considers the social and subjec- 
tive aspects, that are impossible to be detailed in numbers and variables and responds to the universe of meanings, values and attitudes that permeate the social relations. For Holanda (2006) QR has filled spaces that quantitative research was unable to attain, and enters the intersubjective space of human phenomena in an attempt to understand them. According to Pimentel et al. (2009) QR permits understanding the researched phenomena from its complexity and specificity, avoiding generalizations and permitting its singularity and as a proposal to clarify and immerse the layers that obscure the meaning of the phenomena being studied.

According to Dutra (2002), it is through speeches that the experiences are said and revealed, because the facts, events and affections that run along an existential route of each individual, when told, reveal experiences and are constructed and reconstructed through the language, and it is the responsibility of the researcher to collect the experience based on his/her wiliness to understand. Thus, it is through language that participants can reveal their experiences on the subject under study.

The procedures included bibliographical survey, approval by the ethics committee of the Health Science Institute of the Federal University of Pará (Instituto de Ciências da Saúde da UFPA), Opinion no. 868.655, the signature of the Informed Consent Form, and semi-structured interviews. The criteria for inclusion of the informants were: to have between 40 and 55 years old; to be a father or mother of living children; use the virtual social networks once a week; high school education; live in the metropolitan area of Belém and be available to participate in the interviews. The subjects were limited to six because the qualitative design aimed to achieve a deep understanding of the subjects with no concern about representativeness. To choose the participants, the method used was the snowball sampling (Turato, 2003, p. 251). The interviews were developed in the informants' residences and working places. Shortly after, the interviews were transcribed, and for analysis the Sander's Phenomenological method was used, as described by Turato (2003). Sanders (1982, cited in Moreira, 2002, p.122) emphasize that, "in the data analysis, the important thing for the delimitation of a theme is its centrality and its importance and is not a recurrence that appears. After identifying the issues, the researcher organizes them into categories that, at the end of the research, will characterize the structure of the phenomenon studied". To preserve the participants' identity, the original names were replaced by aliases, such as Matheus (51 years old), Marcos (50 years old), Lucas (50 years old), Martha (48 years old), Maria (48 years old) and Esther (46 years old).

\section{Results and Discussion}

The categories for analysis were: 1) Motivation for using the computer; 2) Use of internet and social networks; 3) Posting of contents; 4) Relation with children in the social networks; 5) Need of company, safety, and finding of old social bonds.

1) Motivation for using the computer

All participants reported that their working environment was the first place of contact and intensification in the use of the computer.

Matheus: "when the company made computers available in the offices, we started to have access to internet...”.

Marcos: "I worked for an engineering company and that is when I began to have access to computers".

Lucas: "The first time I had to use a computer was in a company I worked for".

Marta: "My contact was at work. My work consisted of using a computer, I spent all day infront of a computer, I work with spreadsheets".

Maria: "my work demanded computer use, I started to research a few things and the next step was to bring the internet into our house".

2) Use of internet and social networks

Three fathers informed that they enjoyed getting information fast and easily.

Matheus: "Technology is ... learning, to know what is going on in the world”.

Marcos: "It was a constant discovery of innovation, information, a working tool, and eventually leisure...”.

Lucas: "it made communication so easy".

The mothers' reports were diverse: Maria and Esther stated that their initial use was through friends and needed to follow the children in the social networks; Marta was motivated by leisure; and now uses the social 
networks to work.

Esther: "I was interested in these social networks to follow my children and learn about their friends, what they posted, who they were communicating with, to follow them somehow".

Maria: "I joined Facebook because a friend started a group formed by some high school colleagues; I registered and started using it".

Marta: "First, it was for fun, then we started to work in other specific sites; the next step was to use the social networks as a working tool".

The reports from all participants showed that they use the net not only to ease communication, but also as a working tool in different professions. More specifically, WhatsApp ${ }^{\mathrm{TM}}$ worked as a means to speed the processes of work, contact with clients, students, clients, etc.

Marcos: "A lot of work, and leisure in the social network; I have always travelled a lot, and this how I get updated about what is going on in the world".

Esther: "I use it to know if the children are already home, if they are studying, to talk to my boss, to set up a meeting using What App, visit a client".

Lucas: "I use Facebook to learn and teach Spanish and Whats App to talk with my students".

3) Posting content

Matheus, Marcos, Esther and Maria emphasized contents such as Family photos.

Matheus: "Family photos, birthday and reunion photos".

Marcos: "I do not share family photos, and if they mark me I permit".

Esther: "I post pictures of my children's and husband's birthdays, a big family party, fifteen years old birthday or 'a Quinceanera' celebration, I am not the type of person who posts photos of all events I go, such as dinners, etc...”.

Maria: "I post several things, pictures. Everything, I do it, I like it, I post it" .

Lucas informed that he liked to post academic topics, but did not discuss "polemic" items, and Marta stated that she did not like to post personal matters, preferring to post messages that encourage and give hope to other people.

Lucas: "my posting are rather academic, I prefer to post things that enrich me and other people in terms of knowledge, there is no need to use internet to comment on polemic, religious, homophobic issues".

Marta: "to preserve my privacy, I do not post any personal thing. I do not like to expose my life, air the dirty linen in public, I like to say good morning, be nice to a friend, compliment her/him, etc...”.

During their statements, Matheus, Marcos and Maria emphasized sports as their favorite postings, praising their teams and making of fun of their rivals. In a gestalt analysis one observes some differences in the boundaries of exposition of the participants, because some of them do not see a problem in posting photos and exposing their families in the social networks, while others prefer to maintain discretion and avoid issues that may cause controversies, as stated by Polster and Polster (2001: p. 134):

"the boundary of exposition also shares a common ground with all other boundaries. Here, the specific reluctance is how much is observed or acknowledged. The individual may know what is valuable and cannot have objection when adopting this line. He may express it and even act appropriately to that, but he insists in doing it anonymously or in private. He may criticize anonymously or be generous in an anonymous way. $\mathrm{He} /$ she is not willing to accept observations from other people besides the limits he/she establishes".

4) Relation with children in the social network

All participants relate that the use of social networks makes it easier to interact with their children on a daily basis, where to locate them, and to do household tasks. To Matheus, Marcos and Lucas, the social networks are means that improve relations and dialogues with children outside the networks. This kind of information does not appear in the mothers' statements.

Matheus: "we become closer, sometimes it is difficult for parents to talk with their children and, in a way the social network helps this conversation. It is a way to be closer to your children. It does not mean that we 
stop talking to each other personally”.

Marcos: "I think the network brings me closer to my son, and also permits that I see what he has been doing, who he has been related to".

Lucas: "Such closeness provided by the social networks facilitates a lot our emotional contact".

Matheus, Marta, Maria and Esther stated that the social network is important for both parents and children as individuals.

Matheus: "as far as I understand, the use of social network helps in their socialization and also in their education".

Marta: "I do not think that there is a difference on how parents or adolescents use the net; it is there and it is available for everyone".

Maria: "I think that it is another means of interaction with your own children, the world, and other people. I do think it is important”.

Esther: "it is part of modern life for parents, as well, not only to understand your children, considering that nowadays both parents work, we have to take care of the house, take care of ourselves, besides you also have to think about yourself; I think it is interesting for the parents".

On the relation with children on the social networks, the parents stated that children did not like to see them in the social networks but did not criticize. Esther assured that children did not like their parents to participate in social networks, because they did not know how to use them properly. Marcos commented that his daughter asked him to like the pictures she posts.

Marcos: “my daughter tells me that she has posted a photo, 'Dad, like my photo', but I have never heard them criticizing me; I do not see them monitoring me or their mother".

Esther: "They think it is great, and I think the children who do not like it are those whose parents expose too much, do ridiculous embarrassing things, post photos and try to pass as young boys and girls".

The exception was Maria who observed that her children made some criticisms concerning the posting contents, but she also said that she did not care.

Maria: "my son calls me and bothers me with remarks such as 'mother why do you bother to take rainfall photos?' I tell him that I like to post pictures of the moon, take photos of the moon, can you understand? Pictures of the rain, parrots whatever I wish to photo, I do. He asks: 'Mother, do not post them, why do you have to do it you are behaving like a hick!' I do not know why they keep bothering (laughing)!"

During Matheus's, Marcos's, Lucas' and Maria's report, the comments about their relations with their children surged even before the specific questions on the issue. The participants related some facts of their daily life that indicate a positive proximity with their children. This may mean that the social networks permit an extension of existing bonds, but do not create or are the only source of relationship. According to Nicolaci-da-Costa (2005: p.5):

"the results of innumerous national and international researches show that those environments become analogous spaces to 'real' spaces, where unfolds a drama always real of personal relationships”.

In their report, Marta and Esther, the relation with children in the social networks surges as form of control and the relationship outside the net seems to be operational only, concerning domestic activities and social obligations.

Marta: "I stay online with her (daughter) 24 hours a day, I can access her and when she goes out, I want to know where she is, when she is coming back, who is she with; we keep in touch all the time via WhatsApp" Esther: "To be close to my family, because I spend all day away from home, then this is how I know who is and who is not at home. Sometimes, they can't make a call, so they use WhatsApp, which I can answer whenever they need me".

5) Company, safety and recuperation of old social bonds.

In this unit one notices the attribution of unexpected senses to the social networks, converging toward the literature that assures that people do get attached to the original functionality of tools, but create and invent their own way on how to use it, and give a new purpose, according to Lemos (2010: p.106): 
"the relation between the social field and the new technologies is constructed by the symbolic appropriation, where the technical functionality and the economic efficacy add deliria, hope and daily inventions that destabilize the current rules".

The use of the social networks configures innumerous purposes depending on the individual's life experience, because according to Luczinski and Ancona-Lopez (2010), every person is unique and experiments reality in a specific way giving meanings to the world, based on one's life history and way to establish contacts; however, to be-with-the-other, according to Heidegger (2005), one elaborates meanings which are shared, based on this point of view one can stress in the informants' reports the meanings of company, safety, and updating of social bonds. The interlocution between sense and meaning in the processes of relations form the subjectivity and intersubjectivity polarity, according to Pimentel (2003).

To Matheus and Maria, the sense of company attributed to the use of social network is directly related to fear of loneliness, especially during old age. Matheus alleges that the social networks may be an alternative for companionship to old people, but does not include him in this situation. Here one observes a case of projection which, as explained by Kiyan (2006), is a mechanism of defense which occurs when people attribute to other people or the place the characteristics, defects or qualities which are within themselves.

Matheus: "the social networks today are very important when I think about old age, I think that is a very good company for the individual, especially those who are alone, which is not my case, I have many friends".

Maria related that she sometimes feels lonely and uses the social network as a possibility to find company. Based on her statement one may conjecture that in the psychic context she lives a possible deflection, in order words, she uses the ego defense mechanism to avoid contact; and in the geographic context, she may face fear of getting old due to several forms of discrimination and prejudices suffered by old people in Brazil, according to study by Couto et al. (2009).

Besides deflection, the chronic or excessive use of social networks, may establish other mechanisms during the process of ego defense. Thus, Maria, to avoid the solitude she feels and, maybe for painful reasons, or even difficulty to establish strong bonds with people who are not from her family group, may present degrees of confluence in her virtual relations, that is to have problems in discriminating herself by establishing relations of dependence, as explained by Cardella (2002) \& Kiyan (2006).

Maria: "my husband is doing something and then, I sometimes feel alone... then, I visit the web, open entertainment sites. I think it is important for people, especially parents, grandparents, people who is already reaching a certain age to use the internet; I think it works as a company as television did a few years back. Lonely people spent all day watching television, today they spend all day in the internet; it is a kind of company, I think! It works for me!”

The social network as a means to feel safe was characteristic attributed by Matheus, Lucas and Marta.

Matheus: "the way things are in today's world: unsafety, street gangs. I think the social networks inform you where to find your friends or family".

Lucas: "it makes you feel safer, in my case I know if my son is well. Another thing, I can talk to him anytime. It gives you some assurance that everything is okay".

Matheus and Lucas stated that the possibility of being in permanent contact with their children gives them some assurance in relation to urban violence, because they know where and who they are with, confirming a zealous concern with their children.

Marta indicated a presumable private meaning for social network use: need to control illustrated by awiliness to be aware of everything that happens in the world and to her family. Further, it may denote a difficulty to handle her own matters, because she informed that she spends 24 hours with her cell phone on, and feels uncomfortable when she cannot access the internet.

Marta: "if I go out without my cell phone I feel as if I am without my clothes, so I have to go back to pick it up; if I do not do it, I cannot do anything and feel unsafe in the streets without my cell phone, and then I stay in the internet all the time. It is as if I am outside this world without internet I feel unbalanced”. 
As for recuperation of old bonds, Matheus's, Marcos's, Marta's and Esther's report, is shown as interlaced in their history of life and how they found through the social networks,people who were significant in their biographies and that, for several reasons had lost contact. In this respect, the social networks function as detectives which propagate the desire to restore and straighten bonds, and a potential tool for reunions with people, memories mementoes, as shown by Nicolaci-da-Costa (2005: p. 5):

"Convergences, divergences, passions, frustrations, intimate revelations whose anonymity are protected by nicknames (nicks), lies, intrigues, virtual treasons, solidarity, indifference, etc., all of them ingredients of traditional sociability that made their presence permanent”.

Nicolaci-da-Costa (2005) explains that virtual relationships are not entirely negative and may be a complement for relationships with support in the material world.

Matheus: "it is a way to reactivate friendship bonds; we participate of various groups we went to school with as a kid, we remember our plays, etc., they are people we have recently met again. I think it is a good way to meet our old friends again".

Marcos: "the great contribution provided by the social network is to reduce distances and rediscover people”.

Esther: "I found people that I had not seen in a long time, and to me that was very interesting; we spend years without meeting someone, a person you like, and finally you can share some of your life with that person".

\section{Conclusions}

The focus on meanings attributed to the social networks by those who were interviewed permitted a little understanding of the processes of subjectivation of the parents who were born under the social context associated to the advent of internet, and were known as Generation X.

Computer and communication technologies have changed both daily and professional life of people in a significant way; as a result, research on gesltat approach in psychology admits disclosing what is figure, what is deep and mechanisms to avoid physical contact.

It is verified along the study that the research participants use the social network to work, interact with friends, communicate with the family and have fun. Thus, the interpretation of statements is permitted to conclude that Generation X parents have incorporated the use of computer and mobile devices in their daily use.

Their reports on recuperation of old social bonds, as well as communication with their families, that have emerged to the participants are in agreement with Chiuzi, Peixoto \& Fusari (2011), who have stated that Generation $\mathrm{X}$ is more concerned in valuing the family and strongly bonded friendships than with materialism and long and extenuating working journeys.

The study also shows that to some parents like Matheus and Lucas the use of social network affects positively in their relationship with their children, because they are in constant contact with them during the day, and also because it is a tool that also helps dialogue outside the net. To other participants, such as Martha and Esther, it is considered as a tool to locate their children, not to interfere in the dialogue, and their relations at home. There is also a participant who states that internet and social network are similar to men's other basic needs, such as taking a shower and drinking water.

Generation X's parents have sought to overcome difficulties in the use of computer and communication technologies, in other words, in learning to use them to follow their children and establish a close and more affectionate relationship. This conclusion complies with the objectives of the research.

\section{References}

Barcelos, G., Passerino, L., \& Behar, P. (2010). Redes Sociais E Comunidades: Definições, Classificações E Relações. CINTED, Vol. 8, julho. http://seer.ufrgs.br/index.php/renote/article/view/15251/9008

Capra, F. (2008). Vivendo Redes. In F. Duarte, C. Quandt, \& Q. Souza (org.), O tempo das redes (pp. 17-29). São Paulo: Perspectiva.

Cardella, B. H. P. (2002). A Construção do Psicoterapeuta: uma abordagem gestáltica. São Paulo: Summus.

Castells, M. (2010). A sociedade em rede. In A era da informação: economia, sociedade e cultura (Vol. 1, 10th ed.). São 
Paulo: Paz e Terra.

Chiuzi, R. M., Peixoto, B. R. G., \& Fusari, G. L. (2011). Conflito de gerações nas organizações: um fenômeno social interpretado a partir da teoria de Erik Erikson. Temas em Psicologia, 19, 579-590. http://pepsic.bvsalud.org/scielo.php?script=sci_arttext\&pid=S1413-389X2011000200018\&lng=pt\&nrm=iso

Couto, M. C. P. P., Koller, S. H., Novo, R., \& Soares, P. S. (2009). Avaliação de discriminação contra idosos em context brasileiro-ageismo. Psicologia Teoria e Pesquisa, 25, 509-518.

Dutra, E. (2002). A Narrativa Como uma Técnica de Pesquisa Fenomenológica. Estudos de Psicologia (Natal), 7, $371-378$. http://dx.doi.org/10.1590/S1413-294X2002000200018

Heidegger, M. (2005). Ser e Tempo-Parte 1 (15th ed.). Petrópolis: Editora Vozes.

Holanda. A. F. (2006). Questões sobre pesquisa qualitativa e pesquisa fenomenológica. Análise Psicológica, 3, 363-372.

Kiyan, A. M. M. (2006). E a Gestalt emerge: Vida e obra de Frederick Perls. São Paulo: Altana.

Lemos, A. (2010). Cibercultura-Tecnologia e Vida Social Na Cultura Contemporânea (5 ed.). Porto Alegre: Ed. Sulina.

Luczinski, G. F., \& Ancona-Lopez, M. (2010). A psicologia fenomenológica e a filosofia de Buber: O encontro na clínica. Estudos de Psicologia, 27, 75-82. http://dx.doi.org/10.1590/S0103-166X2010000100009

Minayo, M. C. de S. (1994/2013) O Desafio do Conhecimento: Pesquisa qualitativa em saúde (13th ed.). São Paulo: Hucitec.

Moreira, D. A. (2002). O método fenomenológico na pesquisa. São Paulo: Pioneira Thompson.

Nicolaci-da-costa, A. M. (2005). Sociabilidade virtual: Separando o joio do trigo. Psicologia \& Sociedade, 17, 50-57. http://dx.doi.org/10.1590/S0102-71822005000200008

Pimentel, A. (2003). Psicodiagnóstico em Gestalt-Terapia. São Paulo: Summus.

Pimentel, A., \& Diniz, C. (2014). Language Used in Social Networks: Creativity and Self-Expression. Psychology, 5, 21312137. http://dx.doi.org/10.4236/psych.2014.519215

Pimentel, A., Oliveira, I. B., \& Araújo, L. (2009). Pesquisa qualitativas aplicações em terapia ocupacional e psicologia. In A. Pimentel, I. B. S. Oliveira, \& L. S. Araújo (Orgs.), Pesquisa qualitativa em terapia ocupacional (pp. 112-114). Belém: Amazônia.

Polster, E., \& Polster, M. (2001). Gestalt-terapia integrada. São Paulo: Summus.

Recuero, R. (2009). Redes Sociais na Internet. Porto Alegre: Sulina.

Turato, E. (2003). Tratado da metodologia da pesquisa clínico-qualitativa. Petrópolis, RJ: Vozes.

Wasserman, S., \& Faust, K. (1994). Social Network Analysis: Methods and Applications. Cambridge, UK: Cambridge University Press. http://dx.doi.org/10.1017/CBO9780511815478

Wellman, B. (1997). An Electronic Group Is Virtually a Social Network. In S. Kiesler (org.), Culture of Internet (pp. 179-205). Hilsdale, NJ: Lawrence Erlbaum. 